DOI https://doi.org/10.30525/978-9934-26-046-9-53

\title{
ПРИНЦИП SМАRТ В ЛОГІСТИЦІ ВОДНОГО ТРАНСПОРТУ
}

\author{
Слатвінська В. М. \\ аспірантка кафедри господарського права і проиесу \\ Національний університет «Одеська юридична академія» \\ м. Одеса, Україна
}

Майже всі види транспорту відчули вплив цифровізації та інтелектуалізації $[1$, с. 146]. Не секрет що і діяльності водного транспорту торкнулися сучасні тенденції.

B науці відсутне розуміння концепту «принцип SMART в логістиці водного транспорту». Натомість посилання концепції «smart» на логістику вимагає більш широкого обговорення, оскільки в літературі 3 цього питання все ще відсутнє визначення концепції «розумної логістики», більш широке обговорення цього питання відсутнє [2]. Можна зазначити, що «smart-логістика» («розумна логістика» або «інтелектуальна логістика») - це оптимізація інформаційних логістичних потоків, але обов'язково в електронному вигляді, $з$ дедалі більшим відходом від ручного управління в сторону автоматизації за допомогою додатків / сервісів і вже на більш глибокому рівні алгоритмізації процесів [3].

При цьому через те, що «smart-логістика» змінюється в залежності від поточної технології, вона характеризується тимчасовою залежністю і для визначення концепції інтелектуальної логістики необхідно визначити поточний рівень технології [4, с. 25].

The S.M.A.R.T. абревіатура розшифровується як: «Specific, Measurable, Achievable, Realistic and Time-bound» - конкретний, вимірюваний, досяжний, реалістичний та обмежений часом. Які S.M.A.R.T. цілі ставить перед собою така логістика:

1. Не йти на компроміси в питаннях безпеки.

2. Використовувати KРI (ключові показники - графіки та гістограми для моніторингу та вимірювання прогресу).

3. Проводити щоденні зустрічі з підлеглими.

4. Товари, які переміщуються швидко, розміщувати в передній частині складу, повільніші - в задній. Намагатися підтримувати мінімальний рівень завантаженості.

5. Оптимізувати управління простором на складі та щоденною версифікацією запасів. 
Найпопулярніша техніка - це SMART, яка проста і зручна у використанні. Метод дозволяє сформулювати цілі за найбільш важливими критеріями:

Specific - точність або конкретність;

Measurable - вимірність в конкретних показниках;

Achievable aбo attractive - досяжність і привабливість цілей;

Realistic aбo relevant - реальність або значимість завдань;

Timed-bound - обмеженість у часі конкретними датами [5, с. 239].

Вперше пропонуємо розуміти принцип SMART в логістиці водного транспорту як ідея автоматизовано-роботизованої техніки управління логістичними процесами на морському й річковому транспорті за допомогою інтелектуальних транспортних систем (Intelligent Transportation Systems); автоматизації робототехнічних процесів (Robotic Process Automation); штучниого інтелекту (Artificial Intelligence); блокчейну (Blockchain and all Distributed Ledger Technologies); Інтернету речей (IoT)».

Smart-логістика оптимізує процеси, поєднуючи найкращі засоби автоматизації з обладнанням відповідно до різних типів вузлів та сценаріїв, таким чином досягаючи вищої продуктивності та значно покращуючи ефективність роботи бізнесу.

\section{Література:}

1. Гуренко А.В., Зубов С.В. Впровадження інтелектуальних логістичних технологій в інфраструктурний комплекс морського транспорту. Економічний вісник Донбасу. № 3(61), 2020. С. 146-153. doi: 10.12958/1817-3772-2020-3(61)-146-153

2. Dembińska, I., Frankowska, M., Malinowska, M., Tundys, B. Smart Logistics. Kraków-Legionowo: Wydawnictwo edu-Libri. Digital in 2017: Global Overview (2018). Retrieved from: https://wearesocial.com/ specialreports/digital-in-2017- global-overview.

3. Costa R., Jardim-Goncalves R., Figueiras P., Forcolin M., Jermol M., Stevens R. Smart Cargo for Multimodal Freight Transport: When «Cloud» becomes «Fog», IFAC-Papers OnLine. 49 (12), 2016. 121-126.

4. Приходько А.Ю., Шуліка О.О. Застосування принципів «SMART-логістики» при організації доставки вантажів. Збірник матеріалів 82-ї Міжнародної наукової конференції студентів. Секція транспортних технологій. 2020. С. 25-26.

5. Дмитрієва О.І. Державне регулювання інноваційного розвитку транспортної інфраструктури. Дисертація на здобуття наукового ступеня доктора економічних наук за спеціальністю 08.00.03 - економіка 
та управління національним господарством (051 - Економіка). Харківський національний автомобільно-дорожній університет Міністерства освіти і науки України, Харків, 2020. - Український державний університет залізничного транспорту Міністерства освіти і науки України, Харків, 2020. 525 с.

DOI https://doi.org/10.30525/978-9934-26-046-9-54

\title{
ДОСЛІДЖЕННЯ ДИНАМІЧНОЇ НАВАНТАЖЕНОСТІ ТА МІЦНОСТІ НЕСУЧОЇ КОНСТРУКЦІЇ КРИТОГО ВАГОНА З ПРУЖНО-ФРИКЦЙНОЮ ХРЕБТОВОЮ БАЛКОЮ
}

\author{
Фомін О. В. \\ доктор технічних наук, професор, \\ професор кафедри вагонів та вагонного господарства \\ Державний університет інфраструктури та технологій \\ м. Київ, Україна \\ Ловська А. О. \\ кандидат технічних наук, доцент, \\ доцент кафедри інженерії вагонів та якості продукиії \\ Украйнський державний університет залізничного транспорту \\ м. Харків, Україна
}

Рибін А. В.

старший викладач кафедри інженерї вагонів та якості продукиії Украӥнський державний університет залізничного транспорту м. Харків, Україна

Перспективи розвитку транспортної інфраструктури викликають необхідність підвищення ефективності експлуатації залізничного транспорту, як іiі провідної галузі. При цьому особлива увага повинна приділятися технічній забезпеченості залізничного парку.

Для перевезення вантажів, які потребують захисту від атмосферних опадів використовуються криті вагони. Відомо, що найбільш пошкоджуваним елементом несучих конструкцій критих вагонів $\epsilon$ рама. Здебільшого ії пошкодження обумовлені дією значних динамічних навантажень, що виникають в експлуатації. Циклічність дії цих 